\title{
The Role of the AMAN in Strengthening Citizenship Competencies of Indigenous People Regarding to Customary Land Rights
}

\author{
Usman Alhudawi ${ }^{*}$, Iim Siti Masyitoh ${ }^{2}$ \\ ${ }^{1,2}$ Universitas Pendidikan Indonesia \\ *Corresponding author.Email: usmanalhudawi@upi.edu
}

\begin{abstract}
The vulnerability to taking over the living areas of indigenous peoples has led to efforts to increase the potential of citizenship in addressing the issue of communal land in their territories. This study aims to examine the role of Aliansi Masyarakat Adat Nusantara (AMAN) in relation to efforts to build the competence of indigenous peoples in the context of a state. The role of the organization is a very important means of disseminating, building, and shaping the civic competence of indigenous peoples, most of whom have not received formal education. In conducting research on this, researchers used a qualitative approach with a case study research research method. This research was conducted at the secretariat of the big board of Aliansi Masyarakat Adat Nusantara (Rumah AMAN) located in South Jakarta, Jakarta, Indonesia. The results in the study explain that the role of Aliansi Masyarakat Adat Nusantara has a broad impact in increasing the citizenship competence of indigenous peoples in relation to the position of their rights and obligations in the context of being citizens; The efforts and performance of Aliansi Masyarakat Adat Nusantara have an impact on strengthening awareness of the management and spirit of the existence of the customary lands of its territory. The presence of Aliansi Masyarakat Adat Nusantara has an impact on strengthening the citizenship competence of indigenous peoples, with this phenomenon giving rise to the development of the realm of Citizenship Education with the specific target of indigenous peoples.
\end{abstract}

Keywords: The role of the organization, Citizenship competence, Concern, Ulayat

\section{INTRODUCTION}

With the continued development of the passion for democratization in all lines of state life, it is a conceptual and contextual challenge for the implementation of civic education. Today, in the increasingly open information age, citizens continue to develop their position and role in social and state life. So every citizen, both individually and in alliances, has the potential to influence the process of making and implementing public policies related to their interests.

Indigenous peoples as a uniquely Indonesian civic entity are based on the constitutional recognition contained in Pasal 18B ayat 2 UUD NRI Tahun 1945, which until now is still struggling in efforts to present rights that have been recognized in the constitution. The incomplete and not yet concrete recognition of the status and position of the Indonesian indigenous peoples causes friction in interpreting the running of the state system of life.

The notion of friction between the two countries of indigenous peoples is getting wider when issues concerning indigenous peoples often appear in the public. agrarian issues become more frequent issues that appear and are heard by the public. This may be due to the frequent occurrence of reports of citizen demonstrations or conflicts. In general, this is usually due to the occupation of customary land, both from parties who are present from outside the indigenous peoples such as the state, companies, and others on customary land [1].

According to data (Catatan Akhir Tahun KPA, 2019) there were 87 conflicts in the plantation sector, 20 conflicts in the forestry sector which were indicated to have an allusion to the existence of indigenous peoples [2]. Situations that are less favorable to indigenous peoples from insisting on the use of customary natural resources and even the eviction of indigenous peoples from their territories that have been controlled, are used from previous generations. Therefore, it is important to strengthen the knowledge of indigenous peoples regarding the knowledge, skills and character of citizenship (Civic Competence) in order to maintain the existence of their customary territories in the context of the state. 
The condition of indigenous peoples in the field is mostly less prepared with knowledge about information regarding government, politics, law, their role as citizens under certain conditions. With the provision of low civic knowledge, the output for the response of indigenous peoples is only limited to simple efforts such as blockades by the masses or the destruction of company work equipment or relying on physical presence. The limitations of indigenous peoples in the realm of civic knowledge in general have implications for the lack of civic skills and citizenship skills in solutive thinking and involving themselves appropriately in the context of the state.

On the basis of awareness of these weaknesses, it gives rise to collective incentives for citizens to modernize the efforts, movements and management of the masses of indigenous peoples in order to better manage and defend ulayat areas. Character requires three interrelated categories, namely moral knowing, moral feeling and moral action [3]. In addition to being a concern that must become a person's identity, social care is also a value. One of the successes of the accumulation of efforts to unite the potential for managing and fighting for the rights of indigenous peoples is the birth of Aliansi Masyarakat Adat Nusantara (abbreviated as AMAN) on March 17, 1999. Koontz \& O'Donnel explained that the organization is an association that fosters a task/ authority which is then intended as a means of building structural performance engagement, both in the vertical dimension, as well as the horizontal dimension in the agreed roles/positions/tasks in order to achieve common goals [4].

The presence of AMAN has become an organic forum for indigenous communities/villages in building awareness, concern, understanding and education of indigenous peoples in the management of ulayat lands. AMAN strengthens understanding of the relationship between indigenous peoples in the context of the state, such as the constitutional and legal systems, government/political systems, and the role of citizens in democracy, this provision is certainly very useful in situations of struggle to defend customary land. This is driven by the mechanisms and work carried out by the organization, this is in accordance with what was stated by Norman, learning organizational culture creates an environment in which individuals acquire skills and knowledge not only seen as the main responsibility of each member but also supported by interaction and encouragement from others. members of the whole organization [5].

AMAN's role in increasing the citizenship competence of indigenous peoples in managing and defending ulayat rights is a real problem in contemporary Indonesian society. A society with pluralistic conditions that the element that must be anticipated is the reality of such a society that has the potential for conflict [6]. At the same time, these efforts will build civic disposition which can be seen from the readiness of citizens' character in public and private activities as part of the state.
AMAN's role in the management and struggle to defend ulayat areas can be successful when a sense of awareness and concern within the community has been developed. Developing awareness for the existence of a community's ulayat land by citizens at large is not an easy job for AMAN. Continuity of "knowledge-skillscitizenship character" becomes an important formula and must be developed in defending ulayat rights.

For this reason, this study seeks to examine and explore and explore the role of the Aliansi Masyarakat Adat Nusantara (AMAN) in strengthening participation in the struggle for the customary rights of Indonesian indigenous peoples. Based on the above background, the researcher is based on the formulation of the research problem, how is the role of the indigenous peoples of the archipelago alliance in strengthening the civic competence of indigenous peoples in the management concern and struggle to defend ulayat land?

\section{LITERATURE REVIEW}

In research, theoretical research is needed as a basis for research and a general explanation of the reality that occurs. Theories can be in the form of opinions based on research, data-based research, and expert arguments. In this report, at least the researcher uses several clumps of literature to analyze and describe the facts of the research.

Organizations have various functions, among others, to meet and carry out the basic internal needs of the organization, maximize the tasks and workloads of the organization, produce organizational products, campaigns and influence people [7]. Classify organizational roles into four broad groups. First, the organization as a social entity, it is based because it is a symptom of culture, democracy and economy. Organizations are not just machines, so likening an organization along with machines/technology has its own risks. An organization is a collection of people who are bound by interaction, and is not the same as a material entity. Second, goal-directed organizations focus on highly instrumental organizational activities. This means that this is the impact of considerations related to the right mechanism in order to achieve collective goals and individual goals through mechanisms that can be carried out.

Third, the organization is designed in a structured and coordinated program of activities. In this system organization the allocation and coordination of performance is designed in a structured manner. And the fourth organization that has a bond with its external environment makes it a crucial element for the organization to place the organization in broad terms or the organization can take care of situations from outside the organization [8].

In essence learning Pancasila and Citizenship Education (PPKn) seeks to foster and explore students related to attitude or affective development, so that they can play an active role in a democratic state system [9]. The components of Citizenship Education include civic knowledge, civic skills and civic dispositions as elements 
to form civic competence. Civic knowledge is related to the content or things that must be known as citizens. This main component must be realized in the form of important points in compiling Civics learning activities and resources [10]. Civic skill is the ability of citizens to practice their rights and fulfill their obligations as members of a sovereign society. They not only need to master basic civic knowledge, but also need to have relevant intellectual and participatory skills [10]. the character of citizenship implies a public and private character that is important for the continuity and development of constitutional democracy [10].

According to Heidegger, caring comes from the existence of a person's will, which will cause the urge to care, and ability is the source [11].

Furthermore, Muchsin (in Alting, 2011) argues that ulayat rights are those owned by certain indigenous peoples to an area, used as the living area of the community to obtain the results and benefits of natural wealth, including land in the area for the continuation of life and life [12]. The ulayat rights of indigenous peoples are meant to be various powers and provisions in indigenous peoples, which relate to lands that are managed around their living areas [13]. Indigenous peoples need to be positioned on the relevance of indigenous peoples to their land and source of life as entitlements, this is the basis for the subjective identity of indigenous peoples not only seen in their community, but integrally related to their land and environment. Threats to the environment of indigenous peoples are the same as threatening the legal position of these indigenous peoples [14].

\section{METHOD}

\subsection{Research Approach and Design}

In this study using a qualitative approach. Qualitative research method is a way to explore a problem or phenomenon based on a fairly comprehensive picture, manifested in the form of a description of words, and reported in the form of indepth information placed in natural situations [15]. Furthermore, [16], qualitative research is defined as a study that is related to aspects of quality, value/meaning found in field facts. So to describe the findings of the value/meaning obtained, it must pass through the intermediary of language/words. The data findings that are applied are not in numbers, scores, numbers, frequencies, values, or rankings which are often analyzed using mathematical or statistical methods.

Furthermore, this research uses a case study research design. According to Yin, a case study is an empirical research that is applied from various sources to examine contemporary phenomena in the real-life context, whose boundaries with phenomena and scope are not very clear [17].

The reasons specifically for case study research are; The researcher's case study design sees an opportunity to identify research problems into issues and renewable studies and become a tool to explore and thoroughly analyze the research problem or analysis of specific research issues.

\subsection{Participants and Research Site}

Participants are elements of providing data/information needed in research [18]. This research is in the process of obtaining the right data, the selection of participants applies a purposive sampling mechanism. Purposive sampling is a way to determine the representative through certain reasons, it will be in accordance with the provisions, criteria and objectives [19]. The main participants in this study were the administrators of the Archipelago Indigenous Peoples Alliance Organization (AMAN). The selection of participants was based on institutional activities since it was founded in 1999, which focuses on and relates to the struggle for various rights of indigenous peoples, one of which is the right to customary territory.

Furthermore, the place of research was carried out at the Secretariat of the AMAN Executive Board (Rumah AMAN) located in Jakarta, Indonesia.

\subsection{Data collection}

The collection of qualitative research data is carried out starting with giving general questions to the informants, collecting data in the form of words/texts/images and collecting information from a person or research location [20]. Furthermore, the grouping of qualitative data collection techniques is divided into three ways including: 1) observation, 2) interviews, 3) document studies [21]. So we need a way to collect data in accordance with research needs to obtain data in this study.

\subsection{Data Analysis \& Data Validity}

Data analysis is a series of ways to find and write down systematically the data obtained through interviews, observations, field notes and other references with the aim that the results and research findings can be understood by other parties. The data review mechanism is carried out through grouping data, parsing into components, synthesizing, forming patterns, determining important parts to be explored and drawing conclusions. Analysis of qualitative research data was carried out from the beginning of the preparation stage for researchers to participate in collecting data in the field and from the beginning compiling and explaining research problems, which was continued in the process of compiling results and the process of taking research conclusions [22].

Furthermore, in the process of validating research data referring to interactive data analysis according to the Miles and Hurberman model, data analysis is carried out with three main processes consisting of reduction, data presentation, and data inspection [23]. Finally, drawing conclusions or verification is the final sequence in the process of qualitative research work. Researchers will 
draw conclusions and re-examine in terms of the meaning or validity of the conclusions. The meanings compiled by the researcher from the study of the data were first tested for validity, suitability and robustness, the reviewer must be sensitive in exploring meaning, the reviewer uses an emic view through the key informant's point of view and is not based on interpretation of meaning based on the researcher's point of view (ethics) [24].

\section{RESULTS AND DISCUSSION}

AMAN's fundamental role in strengthening the competence of indigenous peoples is the strengthening of traditional knowledge that lives and develops inherited from the ancestors of indigenous peoples. This is a unique phenomenon that modernism has an impact on the unification of indigenous communities into a wider realm which encourages greater visibility for the local community. AMAN's role and work is in line with the opinion that postmodern conditions provide space for local knowledge in relation to powerless communities. Thus work must be done in order to develop a transformative pedagogy that will help build more egalitarian relationships in education and society [25].

In strengthening the competence of indigenous peoples, AMAN seeks transformative education which is carried out in collaboration with the Ministry of Education and Culture. This collaboration has an impact on the accommodation of school development models with non-formal education mechanisms called indigenous schools or traditional schools. Non-formal education is provided by public institutions, publicprivate partnerships, employees, trade unions, media organisations, civic social groups, NGOs and international agencies [26]. From the establishment of this collaboration, villages under AMAN in the last 10 years have built 85 traditional schools. Primarily, the traditional school is designed to strengthen the internal context, such as knowledge, ways of working, and way of life inherited by the ancestors. Which traditional schools are media for regeneration and transformation of knowledge of indigenous peoples so that they are maintained.

The various ways and strategies that are carried out in improving the competence of indigenous peoples depend on the acceptance of a group of indigenous peoples to knowledge that comes from outside. This concern is due to the fact that formal education has not accommodated the values of the teachings held by indigenous peoples. It was stated that [27] A high level of higher education for indigenous people is the shift from protectionist policies to assimilation policies [27]. There is a consideration that the knowledge assimilation model will affect the social system, politics and the life of indigenous peoples in different directions, of course that is a problem. However, when knowledge that comes in from outside is considered by indigenous peoples to have a positive impact and is generally accepted, of course it is not a problem.
In the context of the state, the basic knowledge that must be understood by indigenous peoples is related to the original rights, the concepts and legal basis of the rights of indigenous peoples are contained, the position and problems related to indigenous peoples, the path and method of defending, getting recognition of their rights Some of these items become important in order to continue to grow and strengthen public awareness of the existence of rights to their customary territories. Cholisin said that Citizhenship education is an educational process in order to prepare young citizens for their rights, roles, and responsibilities as citizens to become good citizens, while civic education is citizenship education that is carried out through school, not outside school [28].

The development and strengthening of the citizenship competence of indigenous peoples in adults is carried out through gradual cadre education into three categories. First, the cadre of beginners, namely people who only understand general issues related to indigenous peoples. The second is the regeneration of the movers, namely people who have understood issues related to indigenous peoples from the legal side, as well as politics, and government. Cadres at this stage are educated with the aim of being able to provide assistance, organizing in their traditional village/community. The third is the regeneration of leaders, namely the regeneration of members of organizations/indigenous peoples who have great potential to become movement leaders either in AMAN or movements in their communities. This activity is a routine agenda as the role of the organization strengthens the competence of members through a learning culture. According to Norman, learning organizational culture creates an environment where individuals gain skills and knowledge not only seen as the main responsibility of each member but also supported by interaction and encouragement from members of the entire organization [5].

In addition to being carried out through these basic circulation programs, AMAN conducts a lot of critical education through trainings that are oriented towards direct application in indigenous peoples, both in the internal context and in the context of the state. The relationship between NGOs, civil society, and democratization is often thought of as follows: that although NGOs are part of civil society, they also strengthen it through their activities, which in turn supports the democratic process. Such lines of reasoning are informed by certain visions of 'democracy', 'civil society' and the role that NGOs play in supporting them [29]. The mission to strengthen indigenous peoples as elements of civil society is implemented in activities such as paralegal training, legislation training, economic empowerment training, regional mapping training, participatory mapping training, citizen journalism training and reviewing the law in a critical perspective to the interests of indigenous peoples.

The blockage of democratic mechanisms in the line of submitting the aspirations of indigenous peoples is an irony in the midst of constitutional and national legal 
recognition of the existence and ulayat territories of indigenous peoples. The lack of attention and partisanship from legislative and executive members (regional/central) on the existence of communities and ulayat territories makes the political position of indigenous peoples not so advantageous. The notion that indigenous peoples have special rights, or access to these resources in relation to 'traditional' scientific cultural identities and environments, is meaningless if the holders of these rights and managers cannot be identified and deemed to be recognized by legal criteria. and bureaucracy [30].

Therefore, AMAN encourages its cadres to advance in political contestation in the legislative or executive realms in the districts/cities, provinces and at the center. This is intended so that indigenous peoples can enter into the system, where regulations are produced through a mechanism for receiving aspirations, conversion and then to be decided to become a regulation that has benefits for indigenous peoples. This phenomenon can be explained that the movement against injustice is a series of struggles by the people at the grassroots and middle class levels as well as representative organizations for cultural recognition, economic and social justice and political representation [31]. These movements and efforts in the last seven years have succeeded in encouraging the issuance of 109 legal products of regional regulations related to indigenous peoples.

In Political Studies, this research is a study of the concept of participation of all citizens or every citizen, including members of the AMAN community, has the right to influence the processes of making and implementing decisions made by the government. Public participation can be involved in increasing information, limiting power, proclaiming solutions to problems and power between government and companies and playing a liaison role within the government system [32]. Important participation involving the public and citizens outside can bring about "renewal of power". Participation determines how information is disseminated, develops goals/policies and builds/implements shared goals and work [33]. Therefore, the role of AMAN and other community members in their efforts to maintain the existence and concern for the existence and rights of ulayat is in line with the concept of political participation in influencing the process of forming and implementing a policy related to indigenous peoples issues.

In the study of civic education, this research is very good in order to strengthen the body of knowledge of civic education in the sociopedagogic domain, as well as sociocultural. This is because AMAN's activities as CSOs/NGOs play an important role in civic education at the sociopedagogic level and can be mobilized or used as a medium to build a good society, according to the objectives of Citizenship Education. So the roles of AMAN as a community organization are an important factor in improving the quality of citizens at the community level throughout life. Then it also has an important position in improving the quality of citizens to become good citizens, intelligent and reliable. This is in line with the opinion that civic education opens up the widest opportunities for citizens, expresses their commitment and carries out their active role, to learn to mature themselves, especially regarding legal, moral and functional relationships between citizens and state organizational units and institutions other public institutions [34].

\section{CONCLUSION}

In its work, AMAN continues to strive to influence and organize, train indigenous peoples to better understand concepts, rights, political positions, issues, and fight for their rights in state life. Efforts to increase competence such as training, mentoring, advocacy to strengthen the base in traditional villages. More efforts are needed to transform education and develop teaching methodologies for indigenous peoples in order to improve citizenship competencies so that they have better political influence bargaining power in maintaining their existence.

\section{AUTHORS'S CONTRIBUTIONS}

Authors $^{1} \quad$ : Contribution to concept determination, data collection, analysis and interpretation of research findings, compiling research reports

Authors $^{2}$ : Contribute to concept development and study design, provide input and critical revision of research reports

\section{REFERENCES}

[1] Aliansi Masyarakat Adat Nusantara, Memahami Dimensi-Dimensi Kemiskinan Masyarakat Adat. Jakarta: Aliansi Masyarakat Adat Nusantara (AMAN), ICCO, 2010.

[2] "Catatan Akhir Tahun 2019 Konsorsium Pembaruan Agraria "Dari Aceh Sampai Papua: Urgensi Penyelesaian Konflik Struktural dan Jalan Pembaruan Agraria ke Depan"," Jakarta, 2019.

[3] L. Thomas, Character Matters ( persoalan karakter ): bagaimana membantu anak mengembangkan penilaian yang baik, integritas, dan kebajikan penting lainnya/ penerjemah, Juma Abdu Wamaungo \& jean 166 Antunes Rudolf Zien; editor, Uyu Wahyudin \& Dasim Budimansyah.-Cet.3, Bumi Aksar. Jakarta, 2015.

[4] M. S. P. Hasibuan, Organisasi dan Motivasi (Dasar Peningkatan Produktivitas). Jakarta: PT Bumi Aksara, 2004.

[5] T.-C. Chang, Christina L. H; Lin, "The role of organizational culture in the knowledge management process," J. Knowl. Manag., vol. 19, no. 3, pp. 433455, 2015, doi: 10.1108/JKM-08-2014-0353.

[6] A. A. S. Wahab, Teori dan Landasan Pendidikan 
Kewarganeraan . bandung: Alfabeta, 2011.

[7] A. Muhammad, Komunikasi Organisasi. Jakarta: Sinar Grafika Offset, 2015.

[8] H. Daft, Richard L; Murphy, Jonathan; \& Willmott, Organization Theory and Design. London: Cengage Learning Inc, 2013.

[9] D. M. S. \& R. Nugraha, "Kajian Tentang Penumbuhan Karakter Jujur Peserta Didik Sebagai Upaya Pengembangan Dimensi Budaya Kewarganegaraan (Civic Culture) Di SMA Alfa Centauri Bandung," Model. J. Progr. Stud. PGMI, vol. 6, no. 2, pp. 220-232, 2019.

[10] K. Budimansyah, Dasim; \& Suryadi, PKN dan Masyarakat Multikultural. Bandung: Program Studi Pendidikan Kewarganegaraan, Sekolah Pascasarjana, Universitas Pendidikan Indonesia, 2008.

[11] M. M. Leininger, Caring; an Essential Human Need: Proceedings of Three National Caring., Wayne Stat. Michigan, 1981.

[12] H. Alting, "Penguasaan Tanah Masyarakat Hukum Adat (Suatu Kajian Terhadap Masyarakat Hukum Adat Ternate)," J. Din. Huk., vol. 11, no. 1, pp. 8798, 2011.

[13] B. Harsono, Hukum Agaria Indonesia - Sejarah Pembentukan Undang-Undang Pokok Agraria, Isi dan Pelaksanaannya. Jakarta: Djabatan, 2008.

[14] Y. Arizona, "Memahami Masyarakat Adat: Pendekatan Evolusionis Versus Plularis," Jakarta, 2016.

[15] J. Creswell, Qualitative inquiry \& research design: Choosing among five approaches. California: Sage, 2007.

[16] S. Al muchtar, Dasar Penelitian Kualitatif. Bandung: Gelar Pustaka Mandiri, 2015.

[17] Morissan, Riset Kualitatif. Jakarta: Kencana, 2019.

[18] L. Moleong, Metode Penelitian Kualitatif Edisi Revisi. Jakarta: Remaja Rosda Karya, 2014.

[19] Sugiyono, Memahami Penelitian Kualitatif. Bandung: CV. Alfabeta, 2009.

[20] J. Creswell, Riset Pendidikan-Perencanaan, Pelaksanaan, dan Evaluasi Riset Kualitatif dan Kuantitatif. Yogyakarta: Pustaka Pelajar., 2015.

[21] Mulyadi, Seto; \& dkk, Metode Penelitian Kualitatif dan Mixed Metode (perspektif yang terbaru untuk ilmu- ilmu sosial, kemanusiaan dan budaya). Jakarta: PT RajaGrafindo, 2019.

[22] S. Nasution, Metode Penelitian Naturalistik Kualitatif. Bandung: Tarsito, 2003.

[23] M. Ali, Research Methods In Sustainability Education. Bandung: UPI Press, 2019.
[24] P. A. Usman, H; \& Akbar, Metode Penelitian Sosial, Ketiga. Jakarta: PT Bumi Aksara, 2017.

[25] S. Canagarajah, "Reconstructing Local Knowledge," J. Lang. Identity, Educ., vol. 1, no. 4, pp. 243-259, 2002, doi: http://dx.doi.org/10.1207/S15327701JLIE0104_1.

[26] C. Latchem, "Informal Learning and Non-FormalEducation for Development," J. Learn. Dev., vol. 1, no. 1, pp. 1-13, 2014, doi: http://j14d.org/index.php/ej14d/article/view/6.

[27] L. Rigney, "A First Perspective Of Indigenous Australian Participation In Science: Framing Indigenous Research Towards Indigenous Australian Intellectual Sovereignty," Adelaide, 2001.

[28] Winarno, Pembelajaran Pendidikan Kewarganegaraan. Jakarta: Bumi Aksara, 2013.

[29] C. Mercer, "NGOs, civil society and democratization: a critical review of the literature," Prog. Dev. Stud., vol. 2, no. 1, pp. 5-22, 2002, doi: DOI: $10.1191 / 1464993402 \mathrm{ps} 027 \mathrm{ra}$.

[30] T. M. Li, "Masyarakat Adat, Difference, and the Limits of Recognition in Indonesia's Forest Zone," Mod. Asian Stud., vol. 35, no. 3, pp. 645-676, 2001, doi: 10.1017/S0026749X01003067.

[31] K. Hiariej, Eric; Stokke, "Pendahuluan: Politik Kewargaan Di Indonesia," in Politik Kewargaan Di Indonesia, I., K. Hiariej, Eric; Stokke, Ed. Yogyakarta: Yayasan Obor Indonesia Bekerja sama dengan PolGov Fisipol UGM dan Univeritas Olso, 2018, pp. 1-22.

[32] L. \& D. Wu, "Improvement of regional Environmental Eqality: Government Environmental Governance and Public Participation," Sci. Total Environ., vol. 717, pp. 1-12, 2020.

[33] C. Yao, Xinyue; He, Jia; \& Bao, "Public participation modes in China's environmental impact assessment process: An analytical framework based on participation extent and conflict level," Environ. Impact Assess. Rev., vol. 84, pp. 112, 2020, doi: https://doi.org/10.1016/j.eiar.2020.106400.

[34] Isep, "Peranan Pendidikan Kewarganegaraan Sebagai Pendidikan Hukum Dalam Mengupayakan Internalisasi Hukum Di Kalangan Peserta Didik," J. Penelitian. Pendidik., vol. 13, no. 1, pp. 13-20, 2013. 